Abstracta Iranica Abstracta Iranica

Revue bibliographique pour le domaine irano-aryen

Volume 22 | 2001

Comptes rendus des publications de 1999

\title{
Classification of Knowledge in Islam. Foreword by Seyyed Hossein Nasr, Cambridge, Islamic Texts Society, 1998, $312 \mathrm{p}$.
}

\section{Pierre Lory}

\section{(2) OpenEdition}

1 Journals

\section{Édition électronique}

URL : http://journals.openedition.org/abstractairanica/36732

DOI : 10.4000/abstractairanica.36732

ISSN : 1961-960X

Éditeur :

CNRS (UMR 7528 Mondes iraniens et indiens), Éditions de l'IFRI

\section{Édition imprimée}

Date de publication : 15 mai 2001

ISSN : 0240-8910

\section{Référence électronique}

Pierre Lory, «Classification of Knowledge in Islam. Foreword by Seyyed Hossein Nasr, Cambridge, Islamic Texts Society, 1998, 312 p. », Abstracta Iranica [En ligne], Volume 22 | 2001, document 321, mis en ligne le 17 février 2010, consulté le 13 octobre 2020. URL : http://journals.openedition.org/ abstractairanica/36732; DOI : https://doi.org/10.4000/abstractairanica.36732

Ce document a été généré automatiquement le 13 octobre 2020

Tous droits réservés 


\section{Classification of Knowledge in Islam. Foreword by Seyyed Hossein Nasr, Cambridge, Islamic Texts Society, 1998, $312 \mathrm{p}$.}

\section{Pierre Lory}

Cet ouvrage, qui résulte d'un travail doctoral présenté à l'Université de Philadelphie, présente une comparaison entre les classifications des sciences proposées par Fārābī, par Ǵazzālī et par Quṭb al-Dīn Šīrāzī (dans sa Durrat al-tāj). Chacune de ces classifications est analysée avec détail et érudition, mise en rapport avec l'ensemble de la pensée qui la soutient, formant ainsi trois grandes parties claires et structurées. Le lecteur regrettera simplement que la partie à proprement parler comparative, où les trois systèmes se trouvent confrontés, se réduise à une conclusion certes dense, mais fort brève (huit pages) où sont concentrées les remarques essentielles concernant les critères classificateurs : rapport de chaque auteur à la révélation, à la raison, et définition de l'effort philosophique dans l'ensemble des sciences. L'auteur insiste pour finir sur la conception de l'unité et de la hiérarchie des savoirs qui, selon lui, rapproche ces classifications par ailleurs assez différentes.

\section{INDEX}

Thèmes : 7. Islam 
AUTEURS

PIERRE LORY

EPHE - Paris 